\title{
Raising Tobacco Taxes: The Philippine Experience
}

\author{
Jo-Ann L. Diosana*
}

\begin{abstract}
The 2012 Philippine Sin Tax Reform Law or Republic Act No. 10351 (RA10351) offers important lessons on tobacco taxation and tobacco control. In a span of five years, it increased the excise tax rate on cigarettes to as high as $1000 \%$ for low-priced brands. It is recognized by the international community not only because of the magnitude of the tobacco tax increase that it stipulated but also because of the challenging context within which it was achieved. This article presents the Philippine experience as a case study in pursuing bold reforms in tobacco taxation and tobacco control amidst strong opposition by the tobacco industry. It considers: 1) the key events and factors that led to successful reform of the Philippine tobacco tax system; 2) the impact of higher tobacco taxes on health and the economy; and 3) the emerging challenges in tobacco taxation in the Philippines.
\end{abstract}

Keywords: Policy- taxation- cigarette smoking- tobacco smoking- tobacco control- health financing- tobacco industry

Asian Pac J Cancer Prev, 21, Progress of Tobacco Control in the Western Pacific Region Suppl, 27-31

\section{Introduction}

Before enactment of the Philippine Sin Tax Reform Law (RA 10351) in 2012, the Philippines had some of the most inexpensive cigarettes in the world. The most-sold brand in the country was the cheapest brand among all the ASEAN countries. Total tax as a percentage of the retail price was also one of the lowest in the Region (World Health Organization, 2013).

Consequently, smoking prevalence and tobacco-related morbidity and mortality in the Philippines was one of the highest in the Region. The 2009 Global Adult Tobacco Survey (GATS) reported that $28.3 \%$ of Filipinos aged 15 years and older smoked tobacco. Seven out of the country's 10 leading causes of death were tobacco-related (Asuncion et al., 2012). Economic costs due to the top four tobacco-related diseases - lung cancer, chronic obstructive pulmonary disease, coronary artery disease and cardiovascular disease - were estimated at 188 billion Philippine pesos (PhP) in 2012 (Defensor-Santiago, 2012).

\section{Sociopolitical context of the reform}

Raising taxes on tobacco products, alongside implementing tobacco control policies, has always been a challenge in the Philippines. Rampant corruption and manipulation of public policies to protect vested interests - known in economics as "rent-seeking" - have made the Philippine tobacco industry "the strongest tobacco lobby in Asia" (Alechnowicz and Chapman, 2004). For instance, the Congressional Ways and Means Committee from which all tax policies emanate has long been dominated by legislators from the tobacco-growing districts (Sidel,
2014).

As a result, the tobacco tax structure was problematic and increases in excise taxes had been small and erratic for decades. Varying specific taxes not indexed to inflation were imposed on four cigarette price categories: low-, medium-, high- and premium-priced. Excise tax on low-priced cigarettes increased from PhP 1 per pack in 1997 to only PhP 2.72 in 2012 (Philippines, 1997). Despite increases in the excise tax rates due to amendments to the tobacco tax law in 1997 and 2004, tobacco excise tax collection as a percentage of GDP continued to decline from $0.67 \%$ in 1988 to $0.30 \%$ in 2012 (Bangko Sentral $\mathrm{Ng}$ Pilipinas, 2018; Department of Finance, 2018).

In 2010, reform advocates became hopeful that a meaningful amendment to the Sin Tax Law - which covers excise taxes imposed on tobacco and alcohol products would finally be achieved with the election of Benigno Aquino III to the presidency. During his campaign, Aquino had promised a clean and transparent government, one that might challenge the tobacco industry's usual method of doing business (Sidel, 2014).

At the same time, the Philippines' ratification of the World Health Organization Framework Convention on Tobacco Control (WHO-FCTC) in 2005, in addition to growing evidence on the harms of tobacco consumption, provided impetus for the government and health advocates' push for stronger tobacco control policies. The MPOWER strategy of the WHO-FCTC promotes key interventions to effectively monitor and reduce demand for tobacco. In particular, the " $R$ " in MPOWER gives emphasis to raising the price of tobacco through higher taxes - the single most effective way to prevent people from starting to smoke 
(World Health Organization, 2008).

Nevertheless, the election of Aquino also presented challenges. Included in his campaign was the promise to not impose new taxes but only focus on improving tax administration (ABS-CBN News, 2010). Aquino, known to be a heavy smoker, also did not seem supportive of tobacco control (GMA News, 2010).

\section{Enactment of RA 10351}

It was not until one year into his presidency that Aquino showed interest on reforming the Sin Tax Law. This came about when the "restructuring of excise taxes on alcohol and tobacco products" was included in the list to be prioritized by the Legislative Executive Development Advisory Council (LEDAC) (Business World Online, 2011). Despite inclusion of the Sin Tax Reform in the priority bills of the LEDAC and strong commitment from the Executive, the measure continued to face fierce resistance in both Houses of Congress. Active deliberations on the Sin Tax Reform lasted 14 months. The Senate's final vote of 10-9 in favor of the bill is proof of how difficult it was to pass this measure (House of Representatives, 2012).

Fifteen years after the last restructuring of the Sin Tax Law, RA 10351 was finally enacted on December 20,2012 . The law introduced significant improvements to the excise tax system for both tobacco and alcohol products. Its main features include: (1) substantial increase in excise tax rates; (2) shift from a multitiered system with tax rates based on product prices to one tax rate for all like-products; (3) annual 4\% increase in excise tax; and (4) substantial earmarking of revenues for universal health care (Philippines, 1997).

\section{Key factors in passing the law}

Key to successful passage of RA 10351 was the broad coalition that collaborated to defeat strong lobbying by the tobacco industry. The coalition comprised government officials from various agencies, legislators, former Cabinet officials, development partners and civil society organizations. Members of the informal alliance were diverse and included economic reform-oriented groups, health advocates, medical professional organizations, farmers' groups, academics, media partners and youth groups.

At the core of the broad coalition was a devoted team of government and civil society champions that worked closely to manage the coalition. The coalition was led by experienced activists and officials with a deep understanding of the social, economic and political contexts, and who had been advocating for tax reforms and public health policies for decades. Guided by a whole-ofgovernment or whole-of-society approach, the core team built the coalition, gathered intelligence and identified stakeholders, mapped out the bottom-line objectives, and set the direction of the coalition's legislative and communications strategies.

The strong research capacity of the coalition brought to the fore evidence on the many benefits of reforming the law and exposed false claims made by the tobacco industry. Policy briefs and technical papers were produced covering a wide range of related issues. The robust international literature on the harms of smoking and benefits of tobacco taxes was particularly helpful in making a strong case for raising the tax.

Finally, effectively framing the Sin Tax Law as a health measure and a "win for all", and implementing a timely and dynamic multimedia campaign were important in creating public pressure for the legislation of RA 10351. It was the first time that taxation became a health issue instead of just a revenue measure. The sound evidence was translated into language that was relatable to the youth and the general public. The use of media, particularly social media, was maximized, and a pool of supportive journalists and columnists were constantly updated and engaged (Sidel, 2014).

\section{Impact of RA 10351}

After enactment of RA 10351, price per pack of the most-sold brand increased from PhP 16.22 in 2012 to $\mathrm{PhP}$ 36.39 in 2017. For the same period, the total tax burden per pack more than tripled from $27 \%$ of the retail price to 93\% (Philippine Statistics Authority, 2018).

Tobacco tax revenue grew from PhP 32 billion in 2012 to $\mathrm{PhP} 70$ billion in 2013, reaching PhP 106 billion in 2017 (Department of Finance, 2018). This increase was instrumental in improving the country's fiscal space and credit ratings (Ordinario, 2013).

From 2008 to 2015, smoking prevalence declined in the Philippines, as confirmed by two national surveys, GATS and the National Nutrition Survey (NNS) (see Figure 1). Both survey results mean a three-million reduction in the number of smokers from 2012 to 2015. NNS also shows that the biggest decline in smoking was among the poorest households (Department of Science and Technology Food and Nutrition Research Institute, 2018; Department of Health and Philippine Statistics Authority, 2015).

The law earmarks around $80 \%$ of the incremental revenue for health, resulting in tripling of the national health budget from $\mathrm{PhP} 50$ billion in 2013 to $\mathrm{PhP} 165$ billion in 2019 (Philippines, 2012; Philippines, 2019). This allowed the national government to fully subsidize the health insurance premiums of the poor and the elderly, resulting in 25 million more members and dependents being covered under the national health insurance program (Philippine Health Insurance Corporation, 2013; Philippine Health Insurance Corporation, 2018).

\section{Tobacco tax reform: A tailwind for tobacco control policies}

Moreover, the tobacco tax reform in 2012 created momentum for the legislation of other tobacco control policies and another round of tobacco tax adjustments in the country. The coalition that was formed was maintained, making it a formidable force capable of neutralizing the near-permanent tobacco industry. The breadth and depth of knowledge gained from the passage of RA 10351 greatly encouraged the coalition to pursue more reforms, despite the strong lobby of the tobacco industry.

Shortly after the government started implementing RA 10351 in 2013, then-Senate President Franklin Drilon, who also shepherded the passage of RA 10351 in the 
Table 1. Philippine Laws on Excise Tax on Tobacco Products, 1997 to 2019

\begin{tabular}{|c|c|c|c|c|c|}
\hline Republic Act No. & 8424 & 9334 & 10351 & 10963 & 11346 \\
\hline Date of Enactment & $\begin{array}{l}\text { December 11, } \\
1997\end{array}$ & December 21, 2004 & December 20, 2012 & $\begin{array}{c}\text { December 19, } \\
2017\end{array}$ & July 25, 2019 \\
\hline Number of Tiers & 4 & 4 & $\begin{array}{l}2013 \text { to } 2016: 2 \\
2017 \text { onwards: } 1\end{array}$ & 1 & 1 \\
\hline $\begin{array}{l}\text { Excise Tax } \\
\text { Increase } \\
\text { (cigarettes packed } \\
\text { by machine) }\end{array}$ & $\begin{array}{c}\text { 1998-2000: } \\
12 \%\end{array}$ & $\begin{array}{l}2000-2005: 14 \% \text { to } 86 \% \\
2005-2007: 4 \% \text { to } 12 \% \\
2007-2009: 4 \% \text { to } 11 \% \\
2009-2011: 4 \% \text { to } 10 \%\end{array}$ & $\begin{array}{l}\text { 2011-2013: } 108 \% \text { to } 341 \% \\
2013-2014: 8 \% \text { to } 42 \% \\
2014-2015: 4 \% \text { to } 24 \% \\
2015-2016: 4 \% \text { to } 19 \% \\
2016-2017: 3 \% \text { to } 20 \%\end{array}$ & $\begin{array}{l}\text { 2017-2018: } 16 \% \\
\text { 2018-2020: 7\% } \\
\text { 2020-2022: } 7 \% \\
2022-2024: 4 \%\end{array}$ & $\begin{array}{c}\text { 2018-2020: } 29 \% \\
\text { 2020-2021: } 11 \% \\
\text { 2021-2022: } 10 \% \\
\text { 2022-2023: } 9 \%\end{array}$ \\
\hline $\begin{array}{l}\text { Adjusts tax rates } \\
\text { annually }\end{array}$ & No & No & $\begin{array}{l}\text { Yes, by } 4 \% \text { every year } \\
\text { beginning in } 2018\end{array}$ & $\begin{array}{c}\text { Yes, by } 4 \% \text { every } \\
\text { year beginning } \\
2024\end{array}$ & $\begin{array}{c}\text { Yes, by } 5 \% \text { every } \\
\text { year beginning in } \\
2024\end{array}$ \\
\hline Unitary tax system & No & No & Yes & Yes & Yes \\
\hline $\begin{array}{l}\text { Earmarks for } \\
\text { health }\end{array}$ & No & $\begin{array}{l}\text { Yes, } 2.5 \% \text { of incremental } \\
\text { revenue for the National } \\
\text { Health Insurance Program and } \\
2.5 \% \text { of incremental revenue } \\
\text { for disease prevention program }\end{array}$ & $\begin{array}{l}\text { Yes, more than } 80 \% \text { of } \\
\text { incremental revenue for } \\
\text { universal health care }\end{array}$ & No & $\begin{array}{l}\text { Yes, } 50 \% \text { of } \\
\text { total revenue for } \\
\text { universal health } \\
\text { care }\end{array}$ \\
\hline
\end{tabular}

Senate, expressed his strong commitment to pursue a bill that will replace the text warnings on cigarette packs with graphic health warnings. Drilon, together with other tobacco tax champions in the Senate, posited that picturebased health warnings would complement the recently passed tobacco tax law (Sy, 2013; Macaraig, 2013). True to Drilon's promise, the Graphic Health Warnings Law or Republic Act No. 10643 (RA10643), which requires that graphic health warnings occupy $50 \%$ of the front and back panels of a cigarette pack, was enacted in June 2014 (Philippines, 2014).

As opposed to the pre-RA 10351 period, regular adjustment of tobacco taxes is now the new normal in the Philippines. Two more amendments to the tobacco excise tax law were legislated after RA 10351. The first was a biannual $\mathrm{PhP} 2.50$-increase in the specific tax on cigarettes equivalent to a $16 \%$ tax increase in 2018 under the Tax Reform for Acceleration and Inclusion (TRAIN) Law or Republic Act No. 10963 (RA 10963), which passed in December 2017. The most recent amendment under Republic Act No. 11346 (RA 1136), which was legislated in July 2019, imposed a 29-percent increase in the excise tax on cigarettes in 2020. This will be followed by 11-, 10 -, and 9-percent increases for the years 2021, 2022, and 2023, respectively; after which, an annual adjustment of 5\% will apply. RA 11346 also introduced excise taxes

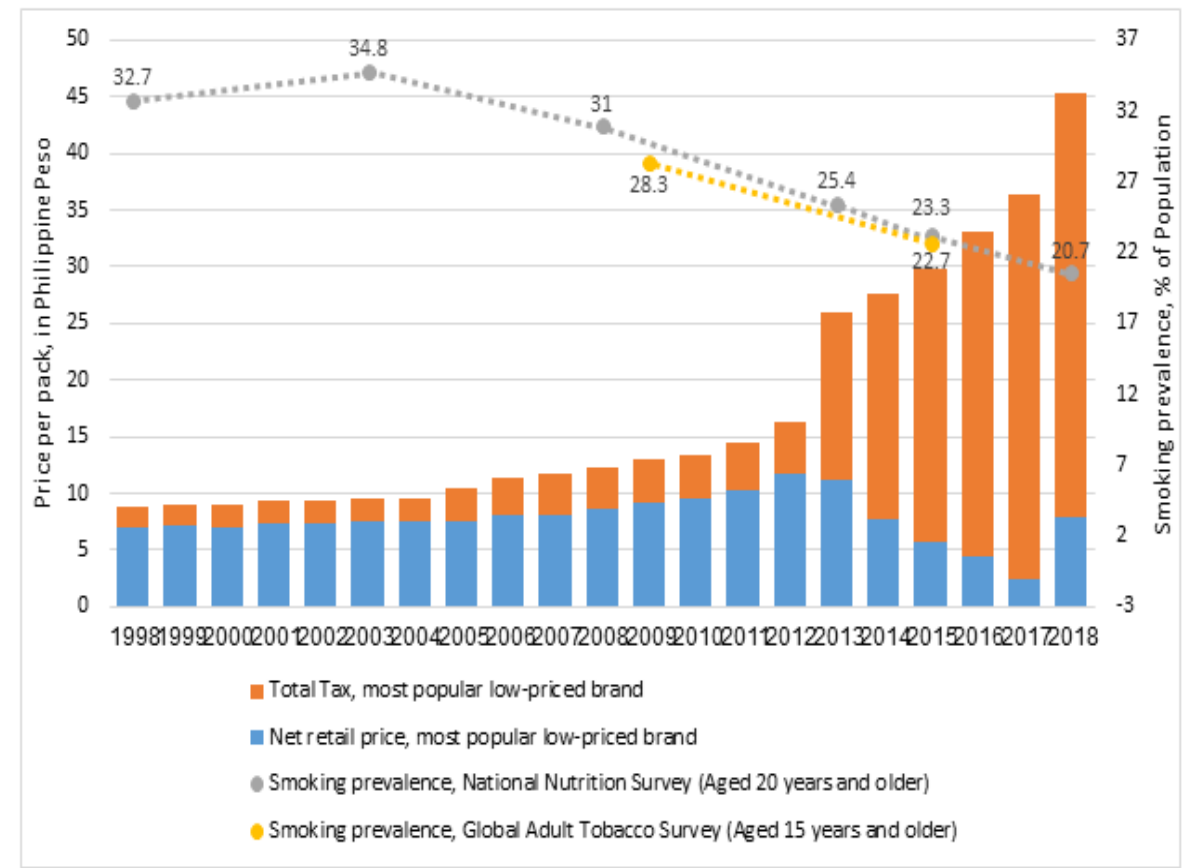

Figure 1. Price and Tax for the Most-Sold Brand among Low-Priced Cigarettes in the Philippines, and Smoking Prevalence Rates, 1998-2018. Philippine Statistics Authority. Monthly price survey, January 1998 to April 2018 (Philippine Statistics Authority, 2018). Department of Science and Technology Food and Nutrition Research Institute. National nutrition survey, 1998, 2003, 2008, 2013, 2015, and 2018 (Department of Science and Technology Food and Nutrition Research Institute, 2018). Department of Health, Philippine Statistics Authority. Global adult tobacco survey: Philippines country report (Department of Health and Philippine Statistics Authority, 2015). 
on heated tobacco (HTPs) and vapor products; albeit differentiated rates on HTPs, salt nicotine vapes, and freebase vapes will apply (Philippines, 1997).

\section{New prospects for tobacco taxation}

If it were not for the inclusion of another tobacco tax increase under the TRAIN Law or RA 10963, the number of smokers would have begun to increase again in 2018 even as RA 10351 stipulates a continued annual increase of $4 \%$ in the excise tax rate. According to a tobacco excise tax simulation model, due to increasing population and strengthening of people's purchasing power concurrent with economic development, the number of smokers would have increased by one million by 2022 even when smoking prevalence would have slightly decreased if RA 10351 would have just been maintained (Van Walbeek, 2010; Action for Economic Reforms, 2017).

Hence, a more effective way to curb smoking is to consider the absolute number of smokers when setting health targets. Targeting just a reduction in the smoking prevalence rates without looking at the absolute number of smokers may fall short of the intended health impact of any tobacco control policy.

Moreover, cigarettes in the Philippines remain cheap compared to those in neighboring countries even as the excise tax of the most-sold brand already stands at more than $85 \%$ of the retail price (Kaiser et al., 2016). More importantly, cigarettes are still affordable relative to other commodities in the Philippines; for example, with the current price of a cup of cooked rice ( $\mathrm{PhP} 10)$, one can already buy two cigarette sticks. In other words, reaching the WHO benchmark of a $70 \%$ excise tax burden may still not be enough to significantly discourage smoking.

Moving forward, the final retail price and some measure of affordability of cigarettes (i.e. price of cigarettes relative to other local commodities), as opposed to the excise tax burden, are more reliable indicators of the effectiveness of a tobacco tax policy. It is also important to monitor the pricing strategy of tobacco companies since this can easily influence the excise tax burden. Case in point, notice how, between 2013 and 2017, the net retail price of cigarettes seemed to have shrunk while the excise tax was increasing; thereby, artificially increasing the excise tax burden (see Figure 1). Tobacco companies were able to absorb the excise tax increases in the first few years of the reform but had to eventually bring back the price to its pre-reform net retail level (in 2018), to improve on their profit margin.

Hence, the $70 \%$ excise tax burden standard by the WHO should not prevent countries from pursuing higher tobacco tax levels. In setting tax level targets, each country should consider other factors, such as the baseline tax structure and tax rates, the tobacco industry's pricing behavior and competitiveness of the market, and the relative price of other basic goods. In terms of measuring affordability, however, comparison of real prices should not be with other countries but should be within country, since each country has a unique context.

Inasmuch as the tobacco industry is also quickly transitioning to harm reduction strategies, taxation as a regulatory policy for the industry's next generation products should be simultaneously pursued alongside increasing excise taxes on the traditional tobacco products. At the very least, heated tobacco products and vape alternatives to smoking should be taxed at the same rate as cigarettes to ensure that the next generation products will not become cheaper alternatives to traditional tobacco products.

Lastly, the series of tobacco control reforms legislated in the past decade has also solidified the public's support for tobacco taxes, which once, like any other tax measure, were considered as unpopular. This implies that further tobacco tax increases, on top of the yearly 5-percent increase, can be expected in the future.

In conclusion, the Philippine experience in raising tobacco tax is proof that close collaboration between government and civil society can trump the strongest tobacco lobby even in an environment conducive to corruption and rent-seeking. It also contributes to the growing evidence that tobacco taxes are an effective policy tool in curbing smoking, expanding the fiscal space, and providing a sustainable source of financing for health. The Philippine tobacco tax reform in 2012 was also instrumental in facilitating the legislation of other tobacco control policies and further tobacco tax increases in the country. While much still needs to be done, the passage of RA 10351 offers valuable lessons for the global advancement of tobacco control and health reforms.

\section{Acknowledgments}

I would like to thank Dr. Florante Trinidad of the WHO Philippines Country Office, and Ashlee Teakle, Mina Kashiwabara, Ramon De Guzman, and Charlotte Kuo-Benit of the WHO Regional Office for the Western Pacific for their support and valuable inputs in the writing of this paper. I would also like to thank my colleagues at Action for Economic Reforms, Filomeno Sta. Ana III and Jenina Joy Chavez, for their guidance and review of this paper.

\section{Statement of Conflict of Interest}

Jo-Ann Diosana is a board member at Action for Economic Reforms, Inc., one of the civil society organizations advocating for higher tobacco excise taxes in the Philippines.

\section{References}

ABS-CBN News (2010, Jan 21). Aquino: no new taxes if elected president. ABS-CBN News. Available from: URL: http:// news.abs-cbn.com/business/01/21/10/aquino-no-new-taxesif-elected-president accessed 02 Oct 2017.

Action for Economic Reforms (2017). Why do we need a tobacco tax provision in the Tax Reform for Acceleration and Inclusion (TRAIN). Action for Economic Reforms, Quezon City.

Alechnowicz K, Chapman S (2004). The Philippine tobacco industry: "the strongest tobacco lobby in Asia". Tob Control, 13, ii71-ii78.

Asuncion IL, Benegas-Segarra A, Timbang TD, Sinson FA, Rebanal LMR (2012). The 2012 Philippine health statistics. Department of Health Epidemiology Bureau, Manila. 
Bangko Sentral Ng Pilipinas (2018). Gross national income (GNI) and gross domestic product (GDP) by industrial origin at current prices, 1981 to 2018 [data file]. Available from: URL: http://www.bsp.gov.ph/PXWeb2007/database/SPEI/ inc_exp_accts/inc_exp_accts_en.asp accessed 18 Sep 2019.

Business World Online (2011, Aug 17). 'Sin' tax reforms in new list of palace priorities. Business World Online. Available from: URL: http://www.bworldonline.com/content.php?sec tion $=$ TopStory $\&$ title $=\& 145 \sin \& 8217$-tax-reforms-in-newlist-of-palace-priorities\&id=36659 accessed 02 Oct 2017.

Defensor-Santiago M (2012, Oct 27). Protect young, poor from smoking. Philippine Daily Inquirer. Available from: URL: http://opinion.inquirer.net/39576/protect-young-poor-fromsmoking accessed 02 Oct 2017.

Department of Finance (2018). Excise tax collection, 1988 to 2017 [unpublished raw data]. Department of Finance, Manila.

Department of Health, Philippine Statistics Authority (2015). Global adult tobacco survey: Philippines country report. Department of Health, Philippine Statistics Authority, Manila.

Department of Science and Technology Food and Nutrition Research Institute (2018). National nutrition survey. Food and Nutrition Research Institute, Manila.

GMA News (2010, May 31). Noynoy says he will smoke even on no-tobacco day. GMA News. Available from: URL: http://www.gmanetwork.com/news/news/nation/192283/ noynoy-says-he-will-smoke-even-on-no-tobacco-day/story/ accessed 20 Nov 2017.

House of Representatives (2012). House bill/resolution history: house bill number 05727,15 th congress. Available from: URL: http://www.congress.gov.ph/legisdocs/?v=billsresults\#15 accessed 02 Oct 2017.

Kaiser K, Bredenkamp C, Iglesias R (2016). Sin tax reform in the Philippines: transforming public finance, health, and governance for more inclusive development. The World Bank, Washington, DC.

Macaraig, A (2013, Jul 11). Smoking kills: Senators want to show you how. Rappler. Available from: URL: https:/www. rappler.com/nation/33536-graphic-health-warning-billssenate accessed 25 Sep 2019.

Ordinario, CU (2013, May 8). Japan grants PH investment grade. Rappler. Available from: URL: https://www.rappler.com/ business/economy-watch/28407-japan-ph-investment-grade accessed 18 Sep 2019.

Philippine Health Insurance Corporation (2013). Stats and charts 2013. Available from: URL: https://www.philhealth.gov.ph/ about_us/statsncharts/snc2013.pdf accessed 18 Sep 2019.

Philippine Health Insurance Corporation (2018). Stats and charts 2018. Available from: URL: https://www.philhealth.gov.ph/ about_us/statsncharts/snc2018.pdf accessed 18 Sep 2019.

Philippine Statistics Authority (2018). Monthly price survey, January 1998 to April 2018 [unpublished raw data]. Philippine Statistics Authority, Quezon City.

Philippines (1997). National internal revenue code (as amended by Republic acts nos. 9334, 10351, 10963, and 11346). Official Gazette of the Republic of the Philippines, Manila.

Philippines (2012). General appropriations act, FY 2013. Official Gazette of the Republic of the Philippines, Manila.

Philippines (2014). The graphic health warnings law. Official Gazette of the Republic of the Philippines, Manila.

Philippines (2019). General appropriations act, FY 2019. Official Gazette of the Republic of the Philippines, Manila.

Sidel JT (2014). Achieving reforms in oligarchical democracies: the role of leadership and coalitions in the Philippines. Developmental Leadership Program, Birmingham pp 9-15.

Sy, M (2013, Jul 12). Drilon revives bill on mandatory graphic health warning on cigarette packs. The Philippine Star. Available from: URL: https://www.philstar.com/ headlines/2013/07/12/964529/drilon-revives-billmandatory-graphic-health-warning-cigarette-packs accessed 25 Sep 2019.

Van Walbeek C (2010). A simulation model to predict the fiscal and public health impact of a change in cigarette excise taxes. Tob Control, 19, 31-6.

World Health Organization (2008). WHO report on the global tobacco epidemic: the MPOWER package. World Health Organization, Geneva. Available from: URL: http://apps. who.int/iris/bitstream/10665/43818/1/9789241596282_eng. pdf accessed 02 Oct 2017.

World Health Organization (2013). WHO report on the global tobacco epidemic: enforcing bans on tobacco advertising, promotion, and sponsorship. Available from: URL: http:// www.who.int/tobacco/global_report/2013/appendix_xi/en/ accessed 02 Oct 2017.

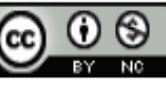

This work is licensed under a Creative Commons AttributionNon Commercial 4.0 International License. 